\title{
Legal Protection to Creditors and Debtors in the Case of Withheld Fiducia Guarantee Object as Evidence of Criminal Case
}

\author{
Andika Putra; Ismansyah; Yulfasni \\ Notary Masters Program, Faculty of Law, Andalas University, Indonesia \\ http://dx.doi.org/10.18415/ijmmu.v6i5.1089
}

\begin{abstract}
Land is a very important means to carry out development, and the problem of land acquisition for these needs is not easy to solve because with the increasing development of land demand is also increasing while the land supply is very limited. Regarding the existence and function of land, there is a legal relationship between humans with land, including the act of transferring rights and release of land rights, in order to provide legal certainty for the act referred to, it is necessary to set forth in the form of a deed made before a Notary or before the District Head or before the Head of the National Land Agency. But today, the public is more entrusted to make this SPPHT before a Notary Public in order to ensure legal certainty, and also the Land Agency has suggested making a transitional deed through a Notary Deed to be more efficient. The method used is empirical juridical research. Research data were collected through field studies through interviews with resource persons to obtain primary data and literature studies to obtain primary data. The focus of this research is to find out and analyze how the process of releasing land rights for development through a notarial deed in the city of Padang. The results showed that 1) the release of rights before the Notary Public through the Signing of the Deed of Relinquishment of Land Rights which first checked all the requirements by the Notary, then the deed is perfectly signed into an authentic deed and guarantees legal certainty. 2) The process of land registration is based on the deed of release of rights made by a Notary in the City of Padang by submitting an application along with the Deed of Relinquishment of Land Rights and other requirements, then reviewing the field and issuing maps by the Land Agency.
\end{abstract}

Keywords: Land; Land Right; Development; Notarial Deed

\section{Introduction}

At the present time it is very difficult to build public facilities on state land, and as a way out is taken by taking land rights. The activity of taking land by the government in the context of implementation for development is what is called land acquisition. Land acquisition for public purposes, is one of the activities carried out by the government in connection with the duties and responsibilities to advance public welfare, in that framework the state is given the authority to control land. 
Land is a very important means to carry out development, and the problem of land acquisition for these needs is not easy to solve because with the increasing development of land demand is also increasing while the land supply is very limited, there are several factors that must be considered in the procurement of land for development needs, that is : ${ }^{1}$

a. Land acquisition for development must meet the requirement of spatial and land use

b. Land development must not cause damage or pollution to the preservation of nature and the environment

c. The use of land may not result in community losses and development interests.

Article 18 of the Law of the Republic of Indonesia Number 5 of 1960 explains that in order to provide land for various community and state needs, the government can revoke land rights by providing appropriate compensation in the manner stipulated by the Act, if efforts are made through the way deliberations fail to produce results. Revocation rights or liberation landowners rights to do with the release of land rights. ${ }^{2}$ The release of land rights is releasing activity legal relationship between holders of land rights to the land under their control to provide compensation on the basis of consensus. The release of this land can only be carried out on the basis of the agreement and agreement of the right-holders both regarding the implementation technique and the amount and form of compensation that will be given to the land.

Related to the existence and function of land, there is a legal relationship between humans and land, including the act of transferring rights, namely sale and purchase, leasing, grants, inheritance and exchange of land, as well as the release of land rights in order to provide legal certainty for the intended acts, then it is necessary to set forth in the form of deed that has been made before a Notary and / or PPAT.

Law of the Republic of Indonesia Number 2 of 2012 concerning Implementation of Land Procurement for Development in the Public Interest, Release of Rights is an activity to terminate legal relations from parties entitled to the state through the National Land Agency. According to this Law, the release of land rights for development through the national Land Agency. But in reality, the deed of release of land rights was made before a notary public so that the strength of proof was perfect.

As in Article 131 paragraph (3) Regulation of the Minister of Agrarian Number 3 of 1997 concerning Implementing Provisions Government Regulation Number 24 of 1997 Concerning Land Registration states that registration of abolition of land rights and ownership rights over flats is caused by the release of land rights by the right holder carried out by the Head of the Land Office based on requests from interested parties by attaching:

1. Notary Deed stating that the relevant holder relinquishes such rights, or

2. A statement from the right holder that the relevant right holder relinquishes the rights made in front and witnessed by the camat of the land concerned, or

3. A statement from the right holder that said right holder relinquished the rights made in front and witnessed by the Head of the Land Office.

\footnotetext{
${ }^{1}$ I Wayan Suandra, Indonesian Land Law, Rineka cipta, Jakarta, Page. 11.

${ }^{2}$ Article 1 number 2 of Law Number 2 of 2012 concerning Land Procurement for Development in the Public Interest.
} 
Regarding the release of rights, the Head of the Padang City Land Office recommends that it be done with a notarial deed ${ }^{3}$, and also at this time the public is more entrusted to make this SPPHT before a notary to ensure legal certainty, for this reason the authors are interested in conducting research under the title Relinquishment of Land Rights for Development through Notarial Deed in Padang City.

\section{Research Methods}

The method used in this thesis research is empirical juridical research, which is research based on field research to get primary data in the field of law. The specifications of this study are descriptive analysts, because this study is expected to obtain data that clearly illustrate what is discussed in this study. The type of data used in this study are primary and secondary data, where secondary data consists of Primary, Secondary and Tertiary Legal Materials. The data collection techniques used for research in the field are interviews and study of documentation documents. While the data obtained from this research will be analyzed using qualitative methods, namely analysis of data without using statistical formulas because the data used are not in the form of numbers. Thus what is used is only by logical explanation of the sentence based on the rules and opinions of experts.

The process of releasing land rights for development through a notary in the city of Padang

The notary who has been given direct authority by the Law to make this Deed of Relinquishment of Land Rights, must make this authentic deed according to the provisions in UUJN, independently, honestly and impartially, so that the strength of the deed is perfect and does not cause problems at a later time. Release of Land Rights that may be made by Notary just for a piece of land / 1 (one) parcels. 4

Notary in making the Deed of Release of Land Rights dahuu should check the validity and completeness of the right base and papers relating to the verification of land ownership so that it can be used as a condition for making a deed. Concerning the correctness of the contents of the documents examined, the Notary cannot test materially with the existence of the relevant land, in other words the Notary does not go to the place where the land is located or see the boundaries of the land as intended in the documents. . The notary public makes the statement in the deed based on the evidence provided by the applicant. $^{5}$

Before the Notary Public makes a Deed of Relinquishment of Land Rights and is signed by the parties, a Notary is obliged to request a Certificate of Non-Cross Dispute (commonly called SS) issued by the Lurah and known by the Camat where the location of the place is located. This letter states that the land to be sold does not dispute with any party. This is done by the Notary as evidence and the basis that the uncertified land does indeed belong to the seller, and the land is not in dispute. ${ }^{6}$

It is also important to note that the Notary must first ascertain whether the land is privately owned, which must also be accompanied by husband or wife approval, so that there is no lawsuit in the future. And also ascertain whether the land is privately owned by the tapping party or if it belongs to the

\footnotetext{
${ }^{3}$ Interview with Mr. Dito Syaferli, S.H M.Kn, Head of the Land Legal Relations Section, Padang City Land Agency, on August 27,2019 at 10.30

${ }^{4}$ Interview with Mr. Dasman, S.H M.Kn, Notary and PPAT in Padang City, on September 172019 at 09.15

${ }^{5}$ Interview with Mr. Alexander, S.H M.Kn, Notary and PPAT in Padang City, on August 252019 at 09.15

${ }^{6}$ Interview with Mr. Dasman, S.H M.Kn, Notary and PPAT in Padang City, on September 172019 at 09.15
} 
people, if the property of the people must fully agree with giving power to the management of the release of this land rights.

To ensure these things, the Notary will ask some requirements to make the Deed of Release of Land Rights namely:

a. The identity of the parties, the National Identity Card (KTP), the Family Card (KK), which releases and receives

b. Letter of Delegation (If authorized)

c. Husband / Wife Agreement

d. Proof of Ownership - Land Certificate

e. Tax Return on Building Land Tax (SPPTB PBB)

The notary then checks that the requirements are true and sufficient to make a Deed of Relinquishment of Land Rights.

In the Deed of Release of Land Rights same as the deed in general, which contains the identity of the parties, the position of the parties, the object of the deed clearly explained the location and extent, and the Articles of the conditions agreed upon. The cost of making this deed is generally as much as agreed by the Notary and the client and paid by the party designated in the deed. For those who receive compensation will be subject to income tax (PPh) of $2.5 \%{ }^{8}$

In the case of making the Deed of land release before a Notary Public as the authorized official as mentioned in Article 131 of Law No. 71 of 2012, the Notary Public as an authorized official encounters several obstacles, such as the Notary just knowing, checking and verifying the formal truth of the evidence. given by the registrar, the Notary does not have the obligation to check the truth on the field, for that reason, there is a concern that there will be a lawsuit in the future which will also make the Notary public be in the position of the defendant as well. To avoid this, the clause usually includes a clause that the parties guarantee the truth of the identity and the evidence provided to the Notary in the case of making this Deed. ${ }^{9}$

The object of the relinquishment of this right is a piece of land with a total area of 1,236 $\mathrm{m} 2$, but based on Article 53 of Law Number 5 Year 2012, namely:

(1) In the framework of efficiency and effectiveness, the procurement of land for Public Interest with an area of no more than 1 (one) hectare can be carried out directly by the Agency requiring land with the Rightful Party, by means of buying and selling or exchanging or other agreed upon ways. both sides.

(2) Land acquisition for public interest which covers not more than 1 (one) hectare as referred to in paragraph (1), is:

a. one stretch; and

b. one budget year.

(3) Land acquisition which is carried out directly as referred to in paragraph (1), can be carried out without going through the stages of conducting land acquisition that is regulated in Law

\footnotetext{
${ }^{7}$ Interview with Mr. Harry Merdeka Samik Ibrahim, S.H M.Kn, Notary and PPAT in Padang City, on August 26, 2019 at 13:00

${ }^{8}$ Interview with Mr. Dasman, S.H M.Kn, Notary and PPAT in Padang City, on September 172019 at 09.15

${ }^{9}$ Interview with Mr. Harry Merdeka Samik Ibrahim, S.H M.Kn, Notary and PPAT in Padang City, on August 26, 2019 at 13:00
} 
Number 2 of 2012 concerning Land Procurement for Development for Public Interest, and its implementing regulations.

(4) Agencies that require land may use the results of appraisal services in determining the value of buying and selling or exchanging or other means agreed by both parties.

(5) Land acquisition as referred to in paragraph (1), is carried out in accordance with the regional spatial plan.

Based on data obtained from the Padang City Land Office that in 2018 there were 10 applications for registration of the release of land rights submitted on the basis of the deed of release made before a notary. Then in 2019 there were 21 applications submitted with the deed of waiver deed made before a notary to register the waiver. from the data of 2 (two) last year can be seen that the entire application for land release was based on land release deed before a Notary, it is considered as efficiency and to ensure legal certainty for the release of these rights.

\section{Land Registration Process Based on the Deed of Land Release Made by a Notary in the City of Padang}

With the Deed of releae of Land Rights that have been made before the Notary Public, then the owner of the right can submit an application for registration of the release of rights in the office of the Padang City Land Agency by bringing the requirements as stated in Article 131 Ministerial Regulation Number 3 of 1997 namely:

(3) Registration of the abolition of rights to land and Ownership Rights for Flats is caused by the release of these rights by the owner carried out by the Head of the Land Office based on requests from interested parties by attaching:

a. 1) Notarial deed stating that the relevant holder release that right, or

2) a statement from the right holder that the relevant right holder release the rights made in front and witnessed by the Camat of the relevant land, or

3) a statement from the right holder that said right holder relinquished the rights made in front and witnessed by the Head of the Land Office,

b. Approval from the Underwriting Right Holder if the said right is encumbered with a Liability;

c. Certificate of rights concerned;

These requirements are the deed of releasing the rights of a notary, then the approval from the Underwriting Right Holder if the right is encumbered with the Underwriting Right, the certificate of the relevant right is added with the identity of the applicant namely the Resident Identity Card (KTP)

Land that has been released through the deed made by a notary public then the consequences of the land is back to the state, and the focus of this research is the release of land rights back to the state which aims to procure land for public use. In the Deed of Release of Land Rights made before a Notary Public, the release of rights is directly addressed to the second party authorized as the executor of the land acquisition for the development of public interest.

After the application enters with other requirements and the Deed of Relinquishment of the Land, then pays the registration fee of Rp.50,000 (fifty thousand rupiah), then the Land Agency is tasked to go down to the field to check and map and prove it by issuing a letter measuring the plot of land that will be 
allocated for the development of the public interest. after everything is complete it will be approved by the Head of the Land Office. ${ }^{10}$

\section{Conclusion}

The process of making a deed of release of rights for development through a Notary in the City of Padang, based on the results of interviews with several notaries and as usual in making the deed, the Notary first asks the applicant to complete several requirements namely, the identity of the parties as the owner of a piece of land to be released the rights and also the recipient of the rights, then proof of ownership of the said piece of land in the form of a certificate and also the United Nations Tax Return on the land to be released. If the requirements are complete, the Notary will make a Deed of Release of Land which contains the identity, position of the parties, the object of the release of rights, and Articles agreed upon by the parties and then perfectly signed by the parties, the Notary and Witnesses. With the deed being signed perfectly, the deed already has a perfect proof of strength as an authentic deed.

The Process of Land Registration Based on the Deed of lan release Made by a Notary Public in Padang City, first by submitting the application for the registration of the waiver of rights by bringing the Deed of Waiver of Land Rights, then paying the registration fee of Rp.50,000 (fifty thousand rupiah), after application for entry along with the completion of other conditions and the Deed of Release of Land Rights, then the Land Agency is tasked with going to the field to check and map and it is proven by the issuance of a measurement letter on a piece of land that will be earmarked for the development of the public interest. After everything is complete, it will be ratified by the Head of the Land Office and the land has been released from the rights and returned to state control which will be used for public interest development.

\section{Suggestion}

For the Notary who is asked to make a Deed of Release of Land Rights to be more careful in checking the requirements submitted by the applicant in relation to the authority of the user in acting to release the land rights, so that in the future the Notary will not be the defendant if a dispute occurs and hope for more information about the process of land registration based on the deed of release of rights made by a notary in Padang city so that the general public can more easily know the procedure.

\footnotetext{
${ }^{10}$ Interview with Mr. Dito Syaferli, S.H M.Kn, Head of the Land Legal Relations Section, Padang City Land Agency, on August 27, 2019 at 10.30
} 


\section{References}

Books

I Wayan Suandra, Indonesian Land Law, Rineka cipta, Jakarta, Page. 11.

Interview

Interview with Mr. Dito Syaferli, S.H M.Kn, Head of the Land Legal Relations Section, Padang City Land Agency, on August 27, 2019 at 10.30.

Interview with Mr. Dasman, S.H M.Kn, Notary and PPAT in Padang City, on September 172019 at 09.15

Interview with Mr. Alexander, S.H M.Kn, Notary and PPAT in Padang City, on August 252019 at 09.15.

Interview with Mr. Harry Merdeka Samik Ibrahim, S.H M.Kn, Notary and PPAT in Padang City, on August 26, 2019 at 13:00,

\section{Copyrights}

Copyright for this article is retained by the author(s), with first publication rights granted to the journal.

This is an open-access article distributed under the terms and conditions of the Creative Commons Attribution license (http://creativecommons.org/licenses/by/4.0/). 